\title{
Lead exposure and plasma mRNA expression in ERBB2 gene
}

\author{
MARGHERITA FERRANTE ${ }^{1}$, CATERINA LEDDA $^{2}$, GEA OLIVERI CONTI $^{1}$, MARIA FIORE $^{1}$, \\ VENERANDO RAPISARDA ${ }^{2}$, CHIARA COPAT ${ }^{1}$, GIUSEPPE SOLE ${ }^{3}$, \\ NIVEA TERZO ${ }^{4}$ and SALVATORE TRAVALI ${ }^{4}$
}

\begin{abstract}
${ }^{1}$ Department of Medical Sciences, Surgical and Advanced Technologies 'G.F. Ingrassia', Section of Hygiene and Public Health; ${ }^{2}$ Section of Occupational Medicine, Department of Clinical and Experimental Medicine, University of Catania, I-95123 Catania; ${ }^{3}$ ISAB S.r.l. - Lukoil, I-96010 Priolo Gargallo; ${ }^{4}$ Section of General Pathology, Department of Biomedical and Biotechnological Sciences, University of Catania, I-95124 Catania, Italy
\end{abstract}

Received December 30, 2016; Accepted February 22, 2017

DOI: $10.3892 / \mathrm{mmr} .2017 .6382$

\begin{abstract}
Epidemiologic data for carcinogenicity in those exposed to lead $(\mathrm{Pb})$ suggests relations with cancers although the totality of the evidence is inconsistent. Alterations in the expression of ERBB receptors have been studied during the development and malignant transformation of different kinds of human tumors where they induce proliferation, angiogenesis and metastasis generation. Relevant clinical data demonstrate the role of ERBB2 receptors in the development and malignancy of human cancers. Therefore, the objective of the present investigation is to give more information on the link between plasma mRNA expression in ERBB2 gene and lead blood levels in a healthy population. Blood samples, socio-demographic, exposure and health data were obtained from 48 healthy men. Real-time polymerase chain reaction assays were performed to detect ERBB2 gene transcripts, $\Delta \Delta \mathrm{Ct}$ method was used to quantify gene expression. $\mathrm{Pb}$ blood level was assayed using high-resolution sector field inductively coupled mass spectrometry and is expressed in $\mu \mathrm{g} / \mathrm{dl}$. Plasma mRNA expression in ERBB2 gene was $6.44 \pm 3.07 \Delta \Delta \mathrm{Ct} ; \mathrm{Pb}$ blood levels was $16.07 \pm 6.74 \mu \mathrm{g} / \mathrm{dl}$. Regression analysis revealed a significant association $\left(\mathrm{r}^{2}=0.5345 ; \mathrm{p}<0.0001\right)$ between $\mathrm{Pb}$ levels and mRNA expression in ERBB2. So far, it has still not been established if the expression of ERBB2 receptors is influenced by $\mathrm{Pb}$ exposure. On the base of the above reported data, we believe an in vitro study might be useful, to understand the molecular mechanisms implicated.
\end{abstract}

Correspondence to: Dr Caterina Ledda, Section of Occupational Medicine, Department of Clinical and Experimental Medicine, University of Catania, Via Santa Sofia 78, I-95123 Catania, Italy E-mail: cledda@unict.it

Key words: HER2/neu, CD340, receptor tyrosine kinase, epidermal growth factor, occupational exposure, occupational assessment, cancer, heavy metals

\section{Introduction}

Lead $(\mathrm{Pb})$ is a metal that is frequently used in many manufacturing settings worldwide and it is a significant environmental pollutant (1). The environmental occurrence of $\mathrm{Pb}$, in developed countries, has decreased significantly in recent decades because of the abolition of most leaded gasoline; however, occupational exposures continue (2-4). Occupations that have had regular exposures include battery-production, battery-recycling, foundry, lead chemical, lead smelter and refinery, leaded-glass, pigment, construction and radiator-repair workers (5-12).

It has been reported that $\mathrm{Pb}$ can cause adverse health effects on the nervous, renal, immune, and reproductive tissues and produce harmful effects on the cardiovascular and hematological systems (1). Pb compounds are also capable of evoking a definite response in various assays including tests for enzyme inhibition, fidelity of DNA synthesis, mutagenicity, carcinogenicity and teratogenicity (2-7).

$\mathrm{Pb}$ also is a suspected carcinogen, with inorganic lead compounds currently identified by the IARC as probably carcinogenic (Group 2A), based on limited evidence in humans and sufficient evidence in animals (12).

Several human cancers are characterized by high levels of proteins that regulate cell cycle progression and proliferation. The HER tyrosine kinase receptor family includes four homologous epidermal growth factor (EGF) receptors: EGFR/ERBB1, HER2/ERBB2, HER3/EHBB3 and HER4/ERBB4 (13). In addition, the HER family of receptors are among the most examined cell signaling families in cancer biology (14). Deregulation of growth-factor signaling attributable to hyperactivation of the ERBB receptors is seen in a wide variety of cancers: breast, bladder, prostate, pancreatic, colon, ovary and non-small cell lung cancers (15-17).

The ERBB2 encodes a $185 \mathrm{kDa}$ glycoprotein and its overexpression occurs primarily as an outcome of gene amplification. It occurs in many cancers such as ovarian, stomach, lung and prostate cancer as well as uterine serous endometrial carcinoma (18-25). ERBB2 is known to form clusters which may be a factor in tumorigenesis $(26,27)$. 
Therefore, the objective of the present study is to give more insight into the link between plasma mRNA expression in ERBB2 gene and $\mathrm{Pb}$ blood levels in a healthy population.

\section{Materials and methods}

Ethics statement. The research protocol was approved by the Ethics Committee of Catania University Hospital (Catania, Italy) and the written informed consent of all subjects was acquired prior to their inclusion in the study.

Study population. During periodic occupational surveillance, 48 refinery workers were visited and invited to participate in this study; none had chronic pathology such as diabetes, hypertension, thyroid, liver, kidney, lung and hematological diseases.

A questionnaire was administered by a trained interviewer to acquire information regarding occupational history, smoking and drinking habits, body mass index, duration of current employment and history of $\mathrm{Pb}$ exposure.

The blood samples were drawn into 2 vacuum tubes, one with EDTA one specific NH Trace Elements Sodium Heparin (Vacuette ${ }^{\circledR}$; Greiner Bio-One International AG, Kremsmünster, Austria).

RNA extraction and ERBB2 $m R N A$ detection. The peripheral blood was centrifuged at $2,850 \mathrm{x}$ g for $10 \mathrm{~min}$ at $4^{\circ} \mathrm{C}$ and the supernatants (plasma) were collected and stored at $-80^{\circ} \mathrm{C}$ until analysis.

RNA was extracted from $1 \mathrm{ml}$ plasma from $5 \mathrm{ml}$ peripheral blood using TRIzol reagent (Invitrogen, Paisley, UK) according to manufacturer's instructions. The total and quality of RNA were calculated by spectrophotometric analysis at $260 \mathrm{~nm}$.

Thirty nanograms of RNA from the plasma or $1 \mu \mathrm{g}$ RNA from mononuclear cells was transcribed to cDNA by a reverse transcriptase in a total $20 \mu 1 \mathrm{RT}$ reaction solution comprising $4.0 \mu \mathrm{l} 5 \mathrm{X}$ First strand buffer, $2.0 \mu \mathrm{M}$ DTT, $20 \mathrm{U}$ RNase inhibitor, $1 \mathrm{mM}$ dNTP, $1 \mu \mathrm{M}$ random primer and $200 \mathrm{U}$ SuperScript ${ }^{\mathrm{Tu}}$ II Reverse Transcriptase (Invitrogen).

Each PCR reaction (final volume of $20 \mu \mathrm{l}$ ) contained $0.5 \mu \mathrm{M}$ primers, $1.6 \mathrm{mM} \mathrm{Mg}^{2+}, 1 \mathrm{X}$ LightCycler ${ }^{\circledR}$ FastStart DNA Master SYBR-Green I (Roche Diagnostics GmbH, Mannheim, Germany). Amplifications were carried out using a LightCycler ${ }^{\circledR} 1.5$ (Roche Diagnostics $\mathrm{GmbH}$ ) with the subsequent setting: i) cDNA denaturation $\left(1\right.$ cycle: $95^{\circ} \mathrm{C}$ for $10 \mathrm{~min})$; ii) quantification $\left(45\right.$ cycles: $95{ }^{\circ} \mathrm{C}$ for $10 \mathrm{sec}$, $57^{\circ} \mathrm{C}$ for $7 \mathrm{sec}, 72^{\circ} \mathrm{C}$ for $10 \mathrm{sec}$ ); iii) melting curve analysis (1 cycle: $95^{\circ} \mathrm{C}$ for $60 \mathrm{sec}, 65^{\circ} \mathrm{C}$ for $15 \mathrm{sec}, 95^{\circ} \mathrm{C}$ for $60 \mathrm{sec}$ ); and iv) cooling ( 1 cycle: $40{ }^{\circ} \mathrm{C}$ for $\left.30 \mathrm{sec}\right)$. Each amplification was made out in triplicates in three different experiments. The condition transition rate was $20^{\circ} \mathrm{C} / \mathrm{sec}$, except for the third segment of the melting curve analysis where it was set to $0.1^{\circ} \mathrm{C} / \mathrm{sec}$. Quantification was obtained by comparing the fluorescence emitted by PCR products at unknown concentration with the fluorescence emitted by external standards at known concentration. In this investigation, fluorescence values were estimated with the second derivative maximum method using LightCycler Data Analysis software (version 1.5; Roche Diagnostics $\mathrm{GmgH}$ ). PCR products specificity was assessed
Table I. Primer sequences.

\begin{tabular}{|c|c|c|}
\hline Primer & $\begin{array}{l}\text { PCR product } \\
\text { (bp) }\end{array}$ & Sequence \\
\hline $\begin{array}{l}\text { ERBB2 } \\
\text { outer }\end{array}$ & 338 & $\begin{array}{l}\text { 5'-ATGTGAAGATGATGAGGATGA-3' } \\
\text { 5'-TAGAAGAGTTGGACAGAATGG-3' }\end{array}$ \\
\hline $\begin{array}{l}\text { ERBB2 } \\
\text { inter }\end{array}$ & 211 & $\begin{array}{l}\text { 5'-GTGATGATCCACTTCCACTTA-3' } \\
\text { 5'-CACTGAGCCATCСТTCTCCTG-3' }\end{array}$ \\
\hline
\end{tabular}

by melting curve analysis followed by gel electrophoresis. The sequences of primers are presented in Table I.

To evaluate the different expression levels we employed a $\Delta \mathrm{Ct}$ method. We analyzed the mean of the crossing points (or crossing threshold $=\mathrm{Ct}$ ) of each sample. The $\mathrm{Ct}$ performs the number of cycles needed to detect a fluorescence over a specific threshold level and it is inversely correlated to the quantity of the nucleic acid template. The $\Delta \mathrm{Ct}$ was calculated by normalizing the mean $\mathrm{Ct}$ of each sample to the mean $\mathrm{Ct}$ of reference gene measured in the equivalent experimental condition. The $\Delta \Delta \mathrm{Ct}$ of each sample was designed by subtracting calibrator $\Delta \mathrm{Ct}$ to sample $\Delta \mathrm{Ct}$. The formula $2^{-\Delta \Delta \mathrm{Ct}}$ was used to calculate the fold change.

$\mathrm{Pb}$ analysis. All samples were diluted 1:10 in a solution containing $0.5 \%$ of sub-distilled $\mathrm{HNO}_{3}$ (VWR, Radnor, PA, USA) and $0.005 \%$ (v/v) of Triton ${ }^{\mathrm{TM}}$ X-100 (Sigma, St. Louis, MO, USA) and analyzed according to Batista et al (28). Certified reference materials were analyzed in each batch and were in agreement with reference values Seronorm ${ }^{\mathrm{TM}}$ Trace Elements Whole Blood (Sero AS, Billingstad, Norway). Iridium at $10 \mathrm{ng} \mathrm{ml}^{-1}$ was used as internal standard.

Statistical analysis. Data were summarized as mean \pm SD for continuous variables and frequencies for categorical variables. Normality was checked by Kolmogrov-Smirnov test and homogeneity of variance by Levene's test. The correlation analysis was applied with logarithmic conversion to identify the correlation between mRNA expression of the ERBB2 gene and blood lead values. P-values $\leq 0.05$ were considered significant. Data analysis was performed using GraphPad Prism version 7 software (GraphPad Software, Inc., La Jolla, CA, USA).

\section{Results}

A total of 48 male workers were included in the study with a mean age of $41.1 \pm 6.6$ years. Years of working was $17.4 \pm 7.7$ years. A total of $40 \%$ of subjects were smokers and $55 \%$ were non-smokers. Mean $\mathrm{Pb}$ blood levels was $16.07 \pm 6.74 \mu \mathrm{g} / \mathrm{dl}$; only two subjects presented $\mathrm{Pb}$ values greater than the reference value $(30 \mu \mathrm{g} / \mathrm{dl})$.

The mRNA expression in the plasma for ERBB2 gene was detected in all subjects with a mean value of $6.44 \pm 3.07 \Delta \Delta \mathrm{Ct}$. Table II summarizes the characteristics of the studied population.

Regression analysis revealed a significant association $\left(r^{2}=0.5345 ; \mathrm{p}<0.0001\right)$ between $\mathrm{Pb}$ levels and the expression of mRNA in ERBB2. Fig. 1 shows the scatter plot of correlation analysis. 
Table II. Population characteristics.

\begin{tabular}{lc}
\hline Workers, $\mathrm{n}(\%)$ & $48(100 \%)$ \\
Gender $(\%)$ & $\mathrm{M}(100 \%)$ \\
Age & $41 \pm 6.6$ \\
Years of working & $17 \pm 7.7$ \\
Smokers & $19(40 \%)$ \\
Non-smokers & $16(55 \%)$ \\
Blood Pb levels $(\mu \mathrm{g} / \mathrm{dl})$ & $16.07 \pm 6.74$ \\
Plasma mRNA expression & $6.44 \pm 3.07$ \\
in ERBB2 gene $(\Delta \Delta \mathrm{Ct})$ & \\
\hline
\end{tabular}

\section{Discussion}

Data showed a correlation between blood lead levels and the expression of plasma mRNA in ERBB2 gene. This is the first study in literature that assesses the association between $\mathrm{Pb}$ and ERBB2.

ERBB receptors have an extracellular ligand-binding region, a single membrane-spanning region and a cytoplasmatic tyrosine-kinase-containing domain. The ERBB receptors are expressed in different tissues of epithelial, mesenchymal and neuronal derivation (29). Futhermore, ERBB2 have been assessed in the development of many human tumors. The structure of ERBB's extracellular region is radically different to that of others. ERBB2 has a fixed conformation that resembles the ligands-activated state: the domain II and IV interaction is absent and the dimerization loop in domain II is exposed $(30,31)$. This structure is consistent with the information that ERBB2 is the favorite partner for the other activated ERBBs, as its interaction is permanently balanced with another ligand-bound receptor (29).

Amplification of ERBB2 leading to overexpression of the receptor, at first observed in a subset of breast cancers, occurs also in other human tumors (29).

The carcinogenic potential of $\mathrm{Pb}$ could be influenced by the activation of intracellular signaling pathways that change cell proliferation, survival, migration and differentiation. $\mathrm{Pb}$ is known to induce extracellular signal-regulated kinase 1 and $2($ ERK1/2) in numerous cell lines including CL3 human non-small cell lung adenocarcinoma cells (30), $1321 \mathrm{~N} 1$ human astrocytoma cells (31) and PC12 rat pheochromocytoma cells (32). $\mathrm{Pb}$ can stimulate the $\alpha$ isoform of protein kinase $\mathrm{C}$ (PKC) membrane translocation and activation, which functions upstream of the ERK1/2 signaling in CL3 (33) and $1321 \mathrm{~N} 1$ (31). It has been reported that activation of the PKC $\alpha$ $\rightarrow$ ERK1/2 signaling contributes to DNA synthesis stimulation in Pb-treated 1321N1 cells (31). In contrast, this signaling increases nucleotide excision repair, promoting survival and preventing mutagenicity in CL3 cells following Pb introduction $(30,33)$.

Cell-surface receptor tyrosine kinases (RTK) participate in the activation of intracellular signaling pathways, as well as the PKC $\rightarrow$ ERK1/2 cascade with subsequent variety of extracellular stimuli $(34,35)$.

The PKC family of serine/threonine protein kinases has been contemplated to be a key target of $\mathrm{Pb}(36-39)$.

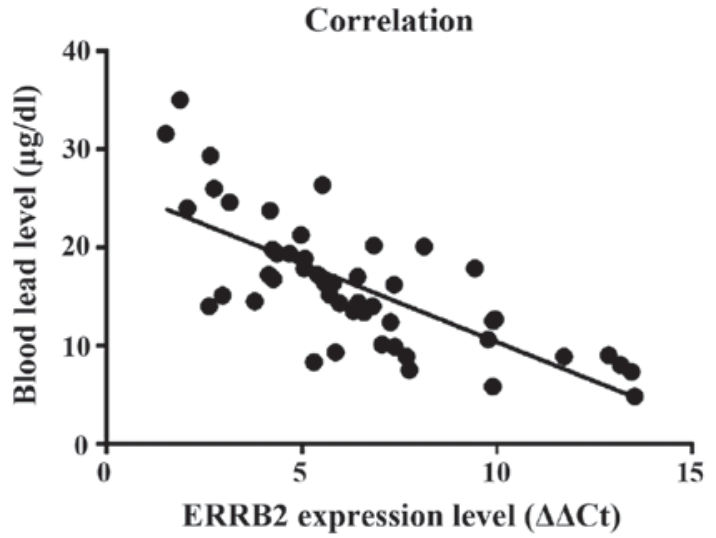

Figure 1. Correlation between blood lead levels plasma mRNA expression in ERBB2 gene.

Studies indicate that $\mathrm{Pb}$ activation of $\mathrm{PKC} \alpha$ can be upstream of ERK1/2 signaling that involves in DNA repair, survival, anti-mutagenesis $(30,33)$ and DNA synthesis (31). Though, no evidence has been shown for the participation of receptor/non-RTKs in the activation of PKC $\alpha \rightarrow$ ERK signaling cascade subsequent to $\mathrm{Pb}$ exposure.

A range of growth factors have been shown to stimulate ERBB2 kinase activity and promote Ras-mediated stimulation of a downstream kinase cascade, which includes the ERK pathway leading to tumor cell growth and migration (40-42).

Future examination is essential to explain whether the $\mathrm{PKC} \alpha$ activation by $\mathrm{Pb}$ is mediated via such an indirect mechanism.

This study thus becomes the basis for addressing the prevention of damage caused by exposure to $\mathrm{Pb}$ related to occupation. Workplace risk prevention and safety rely predominantly on eliminating the risk itself known as primary prevention. However, where this is not technically feasible, technical, organizational, and procedural measures have to be enacted to reduce risk of exposure to a minimum $(43,44)$.

When chemical agents are concerned, primary prevention entails replacing a toxic agent with a non-toxic one. Though, certain mutagenic/carcinogenic agents can be produced in synthetic processes as intermediates or as waste products (45-54).

When risk assessment determines the existence of a health risk, adequate risk control systems must be implemented. These systems are divided into general and personal protection devices (PPD). The former includes adoption of technical and procedural measures, for instance the reduction of environmental pollutants, whereas PPD largely consist of devices worn by employees (such as masks and gloves), preventing direct contact with vapors, fumes and/or potentially polluted material.

In workplaces where risks are recognized, safety procedures must be instituted in accordance with national guidelines. In case of flaws or deficiencies in such guidelines, those in charge of workplace safety are required to refer to the guidelines of internationally recognized organizations, such as the American Conference of Governmental Industrial Hygienists $\left(\mathrm{ACGIH}^{\circledR}\right)$ or National Institute for Occupational Safety and Health (NIOSH). 
Epidemiological studies have demonstrated a causal association between $\mathrm{Pb}$ exposure and the occupational origin of certain types of human cancer (2-7,55-57). The identification of the environmental causes of human cancers has been a long and difficult process. The role of specific components and the interaction of different risk factors in the etiology of human cancer remains to be determined. Regardless of the progress achieved in understanding the cancer process and the impact of this knowledge on treatment, primary prevention remains the most effective approach to reduce cancer mortality in developed and developing countries.

\section{References}

1. Agency for Toxic Substances and Disease Registry (ATSDR) Toxicological Profile for Lead. ATSDR, Atlanta, GA, 2007.

2. Steenland K and Boffetta P: Lead and cancer in humans: Where are we now? Am J Ind Med 38: 295-299, 2000.

3. Fu H and Boffetta P: Cancer and occupational exposure to inorganic lead compounds: A meta-analysis of published data. Occup Environ Med 52: 73-81, 1995.

4. Johnson FM: The genetic effects of environmental lead. Mutat Res 410: 123-140, 1998.

5. Grover P, Rekhadevi PV, Danadevi K, Vuyyuri SB, Mahboob M and Rahman MF: Genotoxicity evaluation in workers occupationally exposed to lead. Int J Hyg Environ Health 213: 99-106, 2010.

6. Olewińska E, Kasperczyk A, Kapka L, Kozłowska A, Pawlas N Dobrakowski M, Birkner E and Kasperczyk S: Level of DNA damage in lead-exposed workers. Ann Agric Environ Med 17: 231-236, 2010

7. Cassini C, Calloni C, Bortolini G, Garcia SC, Dornelles MA, Henriques JAP, Erdtmann B and Salvador M: Occupational risk assessment of oxidative stress and genotoxicity in workers exposed to paints during a working week. Int J Occup Med Environ Health 24: 308-319, 2011.

8. Kašuba V, Rozgaj R, Milić M, Zeljezić D, Kopjar N, Pizent A and Kljaković-Gaspić Z: Evaluation of lead exposure in battery-manufacturing workers with focus on different biomarkers. J Appl Toxicol 30: 321-328, 2010.

9. Rapisarda V, Ledda C, Ferrante M, Fiore M, Cocuzza S, Bracci M and Fenga $C$ : Blood pressure and occupational exposure to noise and lead $(\mathrm{Pb})$ : A cross-sectional study. Toxicol Ind Health 32: 1729-1736, 2016.

10. Rapisarda V, Ledda C, Castaing M, Proietti L and Ferrante M: Potential exposure to carcinogens in low-melting alloys processing. G Ital Med Lav Ergon 35: 73-76, 2013 (In Italian).

11. Valentino M, Rapisarda V, Santarelli L, Bracci M, Scorcelletti M, Di Lorenzo L, Cassano F and Soleo L: Effect of lead on the levels of some immunoregulatory cytokines in occupationally exposed workers. Hum Exp Toxicol 26: 551-556, 2007.

12. International Agency for Research on Cancer (IARC): IARC Monographs on the Evaluation of Carcinogenic Risks to Humans: Inorganic and Organic Lead Compounds. Vol. 87. WHO Press, Geneva, 2006.

13. Arteaga CL and Engelman JA: ERBB receptors: From oncogene discovery to basic science to mechanism-based cancer therapeutics. Cancer Cell 25: 282-303, 2014.

14. Schlessinger J: Cell signaling by receptor tyrosine kinases. Cell 103: 211-225, 2000.

15. Scholl S, Beuzeboc P and Pouillart P: Targeting HER2 in other tumor types. Ann Oncol 12 (Suppl 1): S81-S87, 2001.

16. Ménard S, Casalini P, Campiglio M, Pupa SM and Tagliabue E: Role of HER 2/neu in tumor progression and therapy. Cell Mol Life Sci 61: 2965-2978, 2004.

17. Mendelsohn J: Blockade of receptors for growth factors: An anticancer therapy - the fourth annual Joseph H Burchenal American Association of Cancer Research Clinical Research Award Lecture. Clin Cancer Res 6: 747-753, 2000.

18. Slamon DJ, Godolphin W, Jones LA, Holt JA, Wong SG, Keith DE, Levin WJ, Stuart SG, Udove J, Ullrich A, et al: Studies of the HER-2/neu proto-oncogene in human breast and ovarian cancer. Science 244: 707-712, 1989.

19. Agus DB, Bunn PAJ Jr, Franklin W, Garcia M and Ozols RF: HER-2/neu as a therapeutic target in non-small cell lung cancer, prostate cancer, and ovarian cancer. Semin Oncol 27 (Suppl 11): 53-63, discussion 92-100, 2000.
20. Cox G, Vyberg M, Melgaard B, Askaa J, Oster A and O'Byrne KJ: Herceptest: Her2 expression and gene amplification in non-small cell lung cancer. Int J Cancer 92: 480-483, 2001.

21. Hirsch FR, Varella-Garcia M, Franklin WA, Veve R, Chen L, Helfrich B, Zeng C, Baron A and Bunn PA Jr: Evaluation of HER-2/neu gene amplification and protein expression in non-small cell lung carcinomas. Br J Cancer 86: 1449-1456, 2002.

22. Koeppen HKW, Wright BD, Burt AD, Quirke P, McNicol AM, Dybdal NO, Sliwkowski MX and Hillan KJ: Overexpression of HER2/neu in solid tumours: An immunohistochemical survey. Histopathology 38: 96-104, 2001.

23. Calvo BF, Levine AM, Marcos M, Collins QF, Iacocca MV, Caskey LS, Gregory CW, Lin Y, Whang YE, Earp HS, et al: Human epidermal receptor-2 expression in prostate cancer. Clin Cancer Res 9: 1087-1097, 2003.

24. Osman I, Scher HI, Drobnjak M, Verbel D, Morris M, Agus D, Ross JS and Cordon-Cardo C: HER-2/neu (p185neu) protein expression in the natural or treated history of prostate cancer. Clin Cancer Res 7: 2643-2647, 2001

25. Santin AD, Bellone S, Roman JJ, McKenney JK and Pecorelli S: Trastuzumab treatment in patients with advanced or recurrent endometrial carcinoma overexpressing HER2/neu. Int J Gynaecol Obstet 102: 128-131, 2008.

26. Nagy P, Jenei A, Kirsch AK, Szöllosi J, Damjanovich S and Jovin TM: Activation-dependent clustering of the erbB2 receptor tyrosine kinase detected by scanning near-field optical microscopy. J Cell Sci 112: 1733-1741, 1999.

27. Kaufmann R, Müller P, Hildenbrand G, Hausmann M and Cremer C: Analysis of Her2/neu membrane protein clusters in different types of breast cancer cells using localization microscopy. J Microsc 242: 46-54, 2011.

28. Batista BL, Rodrigues JL, Nunes JA, Souza VC and Barbosa F Jr: Exploiting dynamic reaction cell inductively coupled plasma mass spectrometry (DRC-ICP-MS) for sequential determination of trace elements in blood using a dilute-and-shoot procedure. Anal Chim Acta 639: 13-18, 2009.

29. Hynes NE and Lane HA: ERBB receptors and cancer: The complexity of targeted inhibitors. Nat Rev Cancer 5: 341-354, 2005.

30. Lin YW, Chuang SM and Yang JL: Persistent activation of ERK1/2 by lead acetate increases nucleotide excision repair synthesis and confers anti-cytotoxicity and anti-mutagenicity. Carcinogenesis 24: 53-61, 2003.

31. Lu H, Guizzetti M and Costa LG: Inorganic lead stimulates DNA synthesis in human astrocytoma cells: Role of protein kinase $\mathrm{C} \alpha$. J Neurochem 78: 590-599, 2001.

32. Ramesh GT, Manna SK, Aggarwal BB and Jadhav AL: Lead activates nuclear transcription factor- $\kappa \mathrm{B}$, activator protein-1, and amino-terminal c-Jun kinase in pheochromocytoma cells. Toxicol Appl Pharmacol 155: 280-286, 1999.

33. Wang CY, Lin YW and Yang JL: Activation of protein kinase $\mathrm{C} \alpha$ signaling prevents cytotoxicity and mutagenicity following lead acetate in CL3 human lung cancer cells. Toxicology 250: 55-61, 2008.

34. Gschwind A, Fischer OM and Ullrich A: The discovery of receptor tyrosine kinases: Targets for cancer therapy. Nat Rev Cancer 4: 361-370, 2004.

35. Jorissen RN, Walker F, Pouliot N, Garrett TPJ, Ward CW and Burgess AW: Epidermal growth factor receptor: Mechanisms of activation and signalling. Exp Cell Res 284: 31-53, 2003.

36. Markovac J and Goldstein GW: Picomolar concentrations of lead stimulate brain protein kinase C. Nature 334: 71-73, 1988.

37. Cho HS, Mason K, Ramyar KX, Stanley AM, Gabelli SB, Denney DW Jr and Leahy DJ: Structure of the extracellular region of HER2 alone and in complex with the Herceptin Fab. Nature 421: 756-760, 2003.

38. Harris RC, Chung E and Coffey RJ: EGF receptor ligands. Exp Cell Res 284: 2-13, 2003.

39. Sun X, Tian X, Tomsig JL and Suszkiw JB: Analysis of differential effects of $\mathrm{Pb}^{2+}$ on protein kinase $\mathrm{C}$ isozymes. Toxicol Appl Pharmacol 156: 40-45, 1999.

40. Fiddes RJ, Janes PW, Sivertsen SP, Sutherland RL, Musgrove EA and Daly RJ: Inhibition of the MAP kinase cascade blocks heregulin-induced cell cycle progression in T-47D human breast cancer cells. Oncogene 16: 2803-2813, 1998.

41. Neve RM, Holbro T and Hynes NE: Distinct roles for phosphoinositide 3-kinase, mitogen-activated protein kinase and p38 MAPK in mediating cell cycle progression of breast cancer cells. Oncogene 21: 4567-4576, 2002. 
42. Vijapurkar U,Kim MS and Koland JG: Roles of mitogen-activated protein kinase and phosphoinositide 3'-kinase in ErbB2/ErbB3 coreceptor-mediated heregulin signaling. Exp Cell Res 284: 291-302, 2003

43. Ledda C, Loreto C, Zammit C, Marconi A, Fago L, Matera S, Costanzo V, Fuccio Sanzà G, Palmucci S, Ferrante M, et al: Non-infective occupational risk factors for hepatocellular carcinoma: A review (Review). Mol Med Rep 15: 511-533, 2017.

44. Ledda C and Rapisarda V: Malignant pleural mesothelioma: The need to move from research to clinical practice. Arch Med Res 47: 407, 2016.

45. Ledda C, Loreto C, Matera S, Massimino N, Cannizzaro E Musumeci A, Migliore M, Fenga C, Pomara C and Rapisarda V: Early effects of fluoro-edenite: Correlation between IL-18 serum levels and pleural and parenchymal abnormalities. Future Oncol 12 (23s): 59-62, 2016.

46. Ledda C, Pomara C, Bracci M, Mangano D, Ricceri V, Musumeci A, Ferrante M, Musumeci G, Loreto C, Fenga C, et al: Natural carcinogenic fiber and pleural plaques assessment in a general population: A cross-sectional study. Environ Res 150: 23-29, 2016.

47. Rapisarda V, Ledda C, Migliore M, Salemi R, Musumeci A, Bracci M, Marconi A, Loreto C and Libra M: FBLN-3 as a biomarker of pleural plaques in workers occupationally exposed to carcinogenic fibers: A pilot study. Future Oncol 11 (Suppl): 35-37, 2015.

48. Manzella N, Bracci M, Strafella E, Staffolani S, Ciarapica V, Copertaro A, Rapisarda V, Ledda C, Amati M, Valentino M, et al: Circadian modulation of 8 oxoguanine DNA damage repair. Sci Rep 5: 13752, 2015.

49. Rapisarda V, Loreto C, Ledda C, Musumeci G, Bracci M, Santarelli L, Renis M, Ferrante M and Cardile V: Cytotoxicity, oxidative stress and genotoxicity induced by glass fibers on human alveolar epithelial cell line A549. Toxicol In Vitro 29: $551-557,2015$.
50. Ledda C, Fiore M, Santarelli L, Bracci M, Mascali G, D'agati MG, Busà $\mathrm{A}$, Ferrante $\mathrm{M}$ and Rapisarda V: Gestational hypertension and organophosphorus pesticide exposure: A cross sectional study. Biomed Res Int 2015: 280891, 2015.

51. Rapisarda V, Ledda C, Ricceri V, Arena F, Musumeci A, Marconi A, Fago L, Bracci M, Santarelli L and Ferrante M: Detection of pleural plaques in workers exposed to inhalation of natural fluoro-edenite fibres. Oncol Lett 9: 2046-2052, 2015.

52. Rapisarda V, Bracci M, Nunnari G, Ferrante M and Ledda C: Tetanus immunity in construction workers in Italy. Occup Med (Lond) 64: 217-219, 2014.

53. Costa C, Rapisarda V, Catania S, Di Nola C, Ledda C and Fenga C: Cytokine patterns in greenhouse workers occupationally exposed to $\alpha$-cypermethrin: An observational study. Environ Toxicol Pharmacol 36: 796-800, 2013.

54. Ledda C, Rapisarda V, Bracci M, Proietti L, Zuccarello M, Fallico R, Fiore $M$ and Ferrante M: Professional exposure to basaltic rock dust: Assessment by the Vibrio fischeri ecotoxicological test. J Occup Med Toxicol 8: 23, 2013.

55. García-Lestón J, Méndez J, Pásaro E and Laffon B: Genotoxic effects of lead: An updated review (Review). Environ Int 36: 623-636, 2010.

56. Winder $\mathrm{C}$ and Bonin T: The genotoxicity of lead. Mutat Res 285: 117-124, 1993.

57. Singh Z, Chadha $P$ and Sharma S: Evaluation of oxidative stress and genotoxicity in battery manufacturing workers occupationally exposed to lead. Toxicol Int 20: 95-100, 2013. 